Notes

\title{
THE REEMERGENCE OF ENLIGHTENMENT IDEAS IN THE 1994 FRENCH BIOETHICS DEBATES
}

\begin{abstract}
NAN T. BALL
France has a unique and strong position in the realm of the Rights of Man that the biological sciences and their progress threaten to disrupt. This position stems from Enlightenment thought....

\section{Senator Franck Sérusclat ${ }^{1}$}

But why do you judge so precipitately? Can you be ignorant how widely human nature differs from itself? How opposite its characteristics? How prejudice and manners vary according to times, places, and age? Who is it that can prescribe bounds to nature and say, Thus far shall thou go, and no farther?
\end{abstract}

$$
\text { Jean-Jacques Rousseau }{ }^{2}
$$

\section{INTRODUCTION}

On June 29, 1994, Philippe Séguin, president of the French National Assembly, asked the Constitutional Council to examine three bioethics laws that restricted access to artificial reproductive technologies (ART) to sterile, heterosexual couples of childbearing

Copyright $(9) 2000$ by Nan T. Ball.

1. Les SCIENCES de la VIE ET les DROITS DE L'HOMME 419 (1992) (“La France a une situation singulière et forte dans le domaine des Droits de l'Homme que les sciences de la vie et leurs progrès menacent de bousculer. Elle est issue de la réflexion du siècle des Lumières.").

2. Julie OU la NOUVElle HÉlö̈se 738 (René Pomeau ed., Garnier Frères 1960) (1761) ("Pourquoi décidez-vous ainsi? Savez-vous jusqu'où les hommes diffèrent les uns des autres, combien les caractères sont opposés; combien les moeurs, les préjugés, varient selon les temps, les lieux, les âges? Qui est-ce qui ose assigner des bornes précises à la nature, et dire: $<<$ Voilà jusqu'où l'homme peut aller et pas au delà>>?"). 
age. ${ }^{3}$ In order to judge the constitutionality of the laws and underscore the sanctity of the human body, the Council referred to France's 1789 Declaration of the Rights of Man and Citizen. ${ }^{4}$ In so doing, the Constitutional Council explicitly linked the bioethics questions of today with the eighteenth-century French Enlightenment tradition.

This Note will argue that the action of the Constitutional Council is but one example among many of the ways in which the form and language of the legal debates surrounding ART in France echo Enlightenment ideas. ${ }^{5}$ Close analysis of the 1994 French bioethics debates suggests that Enlightenment polemics about the interrelationship between family, nature, and society provided much of the groundwork for those debates. Through a joint analysis of the French laws and the literary and political tracts of Enlightenment thinker Jean-Jacques Rousseau, this Note demonstrates that the questions posed by Enlightenment philosophers were reformulated in the bioethics debates with a new sense of urgency.

To date, the 1994 French bioethics debates have largely been analyzed through a contemporary political eye. This Note, however, analyzes the 1994 bioethics laws through a literary and historical lens. By means of an interdisciplinary approach, this Note will provide a broader intellectual context for thinking about the bioethics laws and the evolution of French ideas concerning the family and nature. Part I

3. See Thierry Bréhier, M. Séguin souhaite la constitutionnalisation de la protection $d u$ corps humain, LE MONDE, June 30, 1994, at 8; see also Law No. 94-654 of July 29, 1994, J.O., July 30, 1994, p. 11,062; D.S.L. 1994, 29, 411 (defining ART as "clinical and biological practices that permit in vitro fertilization, the transfer of embryos, artificial insemination and all technology with equivalent effects that enable procreation outside of the natural process").

4. See Noëlle Lenoir, French, European, and International Legislation on Bioethics, 27 SUFFOLK U. L. REV. 1249, 1265 (1993). "In reviewing this legislation, the [Constitutional] [C]ourt, for the first time, asserted the constitutional value of the principle of human dignity as a protection against dangerous scientific practices." Id. at 1260.

"Constitutional review in France is not undertaken for the sake of striking down law, but more as a consultative device, where an inquiry is made to the council and ameliorations to the law are suggested." Jonathan F.X. O'Brien, Cinderella's Dilemma: Does the In Vitro Shoe Fit?, 6 TUL. J. INT'L \& COMP. L. 525, 527 n.10 (1998). In a 1971 decision, the Constitutional Court established that it could refer to the 1789 Declaration of the Rights of Man and Citizen to judge the conformity of the legislation to the French Constitution. See id. at 528 n.15.

5. Other contemporary scholars have also described the phenomenon of the reformulation of Enlightenment ideas in the twentieth century. Christie McDonald, Professor of Romance Languages and Literature at Harvard University, has extensively explored related themes. See, e.g., Christie McDonald, Opérateurs du changement: De Miss Polly Baker à Murphy Brown, 19 OEUVRES ET CRITIQUES 69, 69 (1994) (discussing "the relationship between our time and possible rereadings of the eighteenth century"). 
will examine the role various government agencies and institutions played in the formation of the bioethics laws. Part II will demonstrate that French Enlightenment ideas about the close relationship between the well-being of family and society were reformulated and transmuted during the contemporary French bioethics debates. Part III will discuss how the French legislators, like the eighteenth-century philosophers Rousseau critiqued, unquestioningly invoked the authority of "nature" to support restricting access to ART and will argue that this attempt to use nature as a sort of unimpeachable ultimate ethical arbiter can be understood as a selective and transforming interpretation of Enlightenment ideas about nature. Finally, Part IV will suggest that Rousseau, himself a writer of both political tracts and novels, bequeathed not only certain ideas about the questions of family and nature to the twentieth century, but also an important means of conceptualizing and examining ethical questions outside of the constraints of legislative consensus: the novel.

\section{LEGISLATING BIOETHICS IN FRANCE}

This Part will examine some of the contemporary social and political forces that underlie the French legislature's decision to restrict access to Artificial Reproductive Technology (ART). The bioethics laws that the French National Assembly passed on July 9, 1994 allow only sterile, heterosexual couples of procreative age to use artificial insemination and in vitro fertilization procedures. ${ }^{6}$ These restrictions were instituted, in part, to control the threat the legislators thought these technologies posed to the traditional family structure. ${ }^{7}$ The unprecedented availability of ART at the end of the twentieth century appeared to further undermine the predominance of the traditional heterosexual, bi-parental family structure because the technology enabled homosexual couples, virgins, and post-

6. See Law No. 94-654 of July 29, 1994, J.O., July 30, 1994, p. 11,062; D.S.L. 1994, 29, 411.

The CCNE reexamined the 1994 bioethics laws on June 25, 1998, and reaffirmed that

[c] onditions of access to medically assisted reproduction are based on a choice made by society to the effect that the interests of the unborn child are best served by being born and growing up in a family made up of a heterosexual couple. Changes in moral attitudes in the last five years do not seem to justify any modification of these conditions. At this point, therefore, $\mathrm{CCNE}$ is not proposing any modification.

CCNE, Opinion No. 60: Reexamination of the Law on Bioethics, http://www.ccneethique.org/english/avis (last visited Sept. 6, 2000) (on file with the Duke Law Journal).

7. See infra Part II. 
menopausal women to have children. ${ }^{8}$ Unwilling to allow such technological advances to fundamentally alter cultural norms, the French legislature restricted access to ART by championing a normative model of the family.

\section{A. Historical Background}

Various forms of artificial insemination and in vitro fertilization have existed for over two hundred years. ${ }^{10}$ For example, Arnaud de Villeneuve reportedly attempted to artificially inseminate the wife of Henry IV during the sixteenth century. ${ }^{11}$ In 1790, an English doctor named John Hunter injected sperm into the womb of a woman incapable of sexual intercourse. ${ }^{12}$ In vitro fertilization has been successfully used for the eugenic breeding of animals since at least the nineteenth century. ${ }^{13}$ It was not until 1978, though, that the first human baby, Louise Brown, was born as a result of an in vitro fertilization process in the United Kingdom. ${ }^{14}$ The first French "test tube" baby (bébé éprouvette) was born four years later on February $24,1982 .^{15}$ Soon after, the technology developed to freeze embryos and store them for relatively long periods of time before reimplanting them in the womb. ${ }^{16}$

Both the church and the government in France condemned ART as immoral through much of the nineteenth and twentieth centuries. ${ }^{17}$ In 1880, a tribunal in Bordeaux described artificial insemination as "repugnant to natural law" ("répugnante à la loi naturelle"). ${ }^{18}$ The Saint-Office of the Roman Catholic Church condemned the technology in 1897, as did the Protestant Archbishop of Canterbury

\footnotetext{
8. See infra Part II.

9. See infra Part II.

10. See IRMA ARNOUX, LES DROITS DE L'ÊTRE HUMAIN SUR SON CORPS 88 (1994).

11. See id.

12. See Jean-Louis Baudouin \& Catherine Labrusse-Riou, Produire l'homme: DE QUEL DROIT? 26 (1987).

13. See id. at 25 .

14. See id. at 63.

15. See Anne Fagot-Largeault, In France, Debate and Indecision, HASTINGS CTR. ReP., June 1987, at 11.

16. See ARNOUX, supra note 10, at 481. In 1986, two babies were born at the Hospital Béclère after the embryos from which they developed had been frozen for two months. See id. at $481 \mathrm{n} .2$.

17. See BAUdOUIN \& LABRUSSE-RIOU, supra note 12, at 27.

18. Id.
} 
in $1948 .^{19}$ In 1949, the French Academy of the Moral and Political Sciences condemned artificial insemination for its "attack on the foundations of marriage, the family, and the state."

1. Government-Sponsored Sperm Banks. Because of this strongly held moral opposition to ART, French hospitals did not officially provide artificial insemination services for much of the twentieth century. ${ }^{21}$ The procedure was still practiced secretly, however, in some doctors' offices and in private quarters. ${ }^{22}$ There is evidence that 1500-2000 French women might have secretly undergone artificial insemination during the 1970s. ${ }^{23}$ The first officially sanctioned human sperm banks began to appear around the world in 1963, first in the United States, Japan, and Israel, and then finally in Europe. ${ }^{24}$ France established its first government-sponsored sperm banks in $1973 .^{25}$

Professor G. David of the Bicêtre Hospital in Paris worked on improving the efficacy and safety of the long-condemned artificial insemination technology. ${ }^{26} \mathrm{He}$ also created some of the first official ethical guidelines for the donation and use of sperm. ${ }^{27}$ Because of Professor David's efforts, the CECOS (Center for the Study and Conservation of Eggs and Sperm $)^{28}$ was established in the early 1980 s to harmonize and regulate the practices of all French sperm bank centers. $^{29}$ The CECOS played an important role in the development of the recent bioethics legislation because its guidelines formed the

19. See id.

20. NOELle LeNOIR, 1 AUX Frontières de LA VIE: UNE ÉTHIQUE BIOMÉdiCALE À LA FRANÇAISE 28 (1991) ("<<une atteinte aux assises du mariage, de la famille et de la société>>” (quoting l'Académie des Sciences morales et politiques)).

21. See id. at 27-28.

22. See Nicolas Herpin, Obstacles to Sperm Donation in France, in THE ETHICS OF MedicAl CHOICE 48, 57 (John Elster \& Nicolas Herpin eds., 1994).

23. See id. at 58 .

24. See Katia Szleper, Risques et responsabilités médicales dans les nouvelles technologies de la reproduction humaine 122 (1996) (unpublished Docteur en droit dissertation, University of Paris VIII) (on file with author).

25. Professor A. Netter, Head of Endocrinology and Reproduction, Minister of Health, and Professor G. David, Professor of Biology and Reproduction, organized banks at the Necker and Kremlin-Bicêtre hospitals in Paris, respectively. See id.

26. See id.

27. See id.

28. See id. at 125. The French title of the organization is the Centre d'Étude et de Conservation des Oeufs et du Spermes. See id. at 122.

29. See id. at 125. 
basis of various government reports submitted to the legislature on the subject of bioethics. ${ }^{30}$ The CECOS reports were the first to recommend officially that ART only be made available to sterile heterosexual couples who could provide a "normal environment" for the future child.

2. ART Use at the End of the Twentieth Century. More than 10,000 children have been born in France using artificial reproductive techniques since 1982. ${ }^{32}$ The structure of the French health system helps explain this recent widespread use of in vitro fertilization technology. ${ }^{33}$ The eleventh section of the preamble to the 1946 Constitution makes the French citizen's access to health care a constitutional right. ${ }^{34}$ This section affirms that the state must insure that "the child, his mother, and all persons, have access to health care." ${ }^{35}$ Accordingly, the government health system reimburses French citizens for all medical expenditures. ${ }^{36}$ The French government normally reimburses medical procedures up to $80 \%$, but in the case of infertility diagnosis and treatment, the national health insurance system covers the cost of the entire process. ${ }^{37}$

Even though increased ART use has recently become a source of anxiety, initially the state actively extended access to the technology. A 1978 law intended to encourage the birth of children instituted this complete coverage of ART in France. ${ }^{38}$ The law was passed as a means of reversing the trend of decreasing birthrates during the $1970 \mathrm{~s}^{39}$ - a trend that had also led to a resurfacing of old natalist rhetoric. $^{40}$

30. See id. at 126.

31. See id. at 125-26.

32. See ARNOUX, supra note 10 , at 475.

33. See Lenoir, supra note 4, at 1252.

34. See id.

35. Id.

36. See Fagot-Largeault, supra note 15 , at 10.

37. See id.

38. See id.

39. See id.

40. Natalist rhetoric was very prominent in France after the birth rate was almost cut in half following World War I. See William H. SchneIDER, Quality AND QuantiTy 119 (1990). Various measures were taken by the government to counteract this trend. On July 31, 1920, a law was passed banning abortion. See id. at 120. Prizes were awarded to large families. See id. Politicians bragged about how many children they had in campaign literature. See id. at 119. Furthermore, a center was founded in Strasbourg for the sole purpose of helping young married couples raise children. See id. at 124. 
The housing of ART in institutions such as the CECOS and the public health system helped attract the attention of the general public to the potential of the technology. Even though biomedical techniques like artificial insemination had been in use for over one hundred years, the twentieth-century institutionalization of ART and improvements in the technology itself helped make the techniques appear threatening on a larger scale. ${ }^{41}$ The French press played an important role in focusing national attention on the questions ART raised for the notions of the family and the boundaries of nature. ${ }^{42}$ For example, French news programs featured the test tube baby Amandine nightly in $1982 .^{43}$ In 1983, a woman from Nîmes attracted media attention when she decided to act as a surrogate mother for her twin sister. ${ }^{44}$ In August of 1984, the media focused the nation's attention on twenty-three-year-old Corinne Paraplaix's attempt to sue the CECOS for access to sperm that her husband had deposited before his death from testicular cancer. ${ }^{45}$ Corinne Paraplaix hoped to use this sperm for an in vitro fertilization process so that she might bear her dead husband's child. ${ }^{46}$ In a controversial decision, a French court eventually granted her request. ${ }^{47}$

These highly publicized incidents triggered widespread public debate about the difficult moral, philosophical, and legal dilemmas ART engendered. ${ }^{48}$ Could frozen sperm be treated as property? Was post-mortem insemination the equivalent of "orphaning" a child at birth? As the courts struggled with cases like Corinne Paraplaix's, it became apparent that no existing legal guidelines could adequately address these issues. ${ }^{49}$ The French press and public therefore demanded an immediate response from the government to these moral dilemmas. ${ }^{50}$

41. See infra notes $102-03$ and accompanying text.

42. See Fagot-Largeault, supra note 15, at 10-12.

43. See id.

44. See id. at 11.

45. See id.

46. See id.

47. See id.

48. See id.

49. See id.

50. See Jean-Claude Charnet \& Marie-Dominique Cadieu, Elements pour une RÉFLEXION BIOÉTHIQUE EN CLASSE: DE LA PROCRÉATION À LA BIOÉTHIQUE [ELEMENTS FOR Bioethical Reflection in Class: From Procreation to Bioethics] 55 (1996) ("Par l'intermédiaire des médias, des réponses étaient instamment demandées ...." This translates as: "By the intermediary of the media, answers [to these bioethics dilemmas] were demanded 


\section{B. The French National Bioethics Committee}

To help address these emerging bioethics dilemmas, Président François Mitterand officially inaugurated a national bioethics committee, called the CCNE (Comité Consultatif National d'Éthique pour les Sciences de la Vie et de la Santé), on February 23, $1983 .{ }^{51}$ The committee's explicit purpose is the examination and exploration of the ethical questions engendered by scientific progress; ${ }^{52}$ Article 23 of the 1994 bioethics laws extended this role to include the publication of recommended courses of action for the government and society. ${ }^{53}$ Both scientists and non-scientists make up the membership of the CCNE; the government appoints philosophers, researchers, theologians, and ethicists to the committee..$^{54}$ The committee has no actual legislative power, but the advisory reports (avis) it publishes about biomedical ethics are highly influential. ${ }^{55}$ The French legislature relied heavily on the CCNE's advisory reports ${ }^{56}$ during the 1994 bioethics debates. ${ }^{57}$

\section{Drafting the 1994 French Bioethics Laws}

The National Assembly voted bioethics law No. 94-654 into effect on July 29, $1994 .^{58}$ The provisions of Article L. 152.1 and 152.2

instantly ....").

51. See Anne Fagot-Largeault, Normativités biologique et sociale, in FONDEMENTS NATURELS DE L'ÉTHIQUE 191, 212 (Jean-Pierre Changeux ed., Editions Odile Jacob 1991). Anne Fagot-Largeault, a member of the CCNE, remarked, "To address the ethical problems engendered by biomedical advances, how have our societies proceeded? By naming committees and commissions...." Id. ("Pour régler les problèmes d'éthique issus des avancées biomédicales, comment nos sociétés ont-elles procédé? Elles ont nommé des comités ou commissions ....").

52. See Szleper, supra note 24, at 117.

53. See Law No. 94-654 of July 29, 1994, J.O., July 30, 1994, p. 11,067; D.S.L. 1994, 29, 411.

54. See Claire Ambroselli, France: A National Committee Debates the Issues, Hastings CTR. REP., Dec. 6, 1984, at 20.

55. See Fagot-Largeault, supra note 15, at 11-12 (describing the response of government officials and legislators to the 1984 advisory report on ART); see also SUZANNE RAMEIX, FONDEMENTS PHILOSOPHIQUES DE L'ÉTHIQUE MEDICALE 13, 118-24 (1996) (describing how doctors in the late twentieth century have increasingly turned to ethics scholars and theologians for guidance in responding to new medical concerns and noting the recent growth in the number of ethics committees).

56. See, e.g., Avis No. 3, Opinion on Ethical Problems Arising out of Artificial Reproductive Techniques (Oct. 23, 1984), http://www.ccne-ethique.org (on file with the Duke Law Journal); Avis No. 18, Update on Studies Undertaken by the Committee Regarding Gamete and Embryo Donation (Dec. 15, 1989), http://www.ccne-ethique.org (on file with the Duke Law Journal).

57. See infra notes 62-70 and accompanying text.

58. See Law No. 94-654 of July 29, 1994, J.O., July 30, 1994, p. 11,060; D.S.L. 1994, 29, 411. 
of this law are as follows:

Art. L. 152.1- [Artificial Reproductive Technology] includes clinical and biological practices that permit in vitro fertilization, the transfer of embryos, artificial insemination and all technology with equivalent effects that enable procreation outside of the natural process.

Art. L. 152.2- [Artificial Reproductive Technology] is intended to respond to the parental demand of a couple.

Its object is to remedy infertility of a pathological character which has been medically diagnosed. Its object is also to avoid the transmission of a particularly grave illness to a child.

The man and woman forming the couple must be alive, of procreative age, married or able to prove that they have lived together for at least two years and have consented to the transfer of embryos and insemination. ${ }^{59}$

The above articles restrict access to ART to heterosexual couples of procreative age. Post-mortem and post-menopausal insemination are effectively banned, as is the use of artificial procreative technology by homosexual couples or single women. The laws ensure that ART can only be used in response to medical or clinical needs, i.e., as a means of circumventing medically diagnosed infertility. ${ }^{60}$

The bioethics legislation ultimately passed by the National Assembly required two years of debate in the French Parliament. ${ }^{61}$ The laws were based primarily on the research and recommendations of various reports requested by the government over the period of almost a decade. ${ }^{62}$ From the beginning, the government reports consistently recommended limiting access to ART. In 1986, during the Mitterand presidency, Prime Minister Jacques Chirac requested the first of these reports from the Conseil d'État (the Council of State, a body made up of senior civil servants whose primary role is to advise the government). ${ }^{63}$ Guy Braibant (the former head of the Conseil d'État) prepared the report and addressed issues including

\footnotetext{
59. Id. at 11,062 .

60. See id.

61. See Jean-Yves Nau, Bioethics Laws in France, 344 LANCET 48, 48 (1994).

62. See id.

63. See Avis No. 18, supra note 56.
} 
prenatal diagnostics, ART, and embryo donation. The Braibant report recommended that ART remain a purely medical technique and explicitly denounced use of the technology by homosexuals and post-mortem insemination. ${ }^{64}$ When it was finally published in 1988 , some legislators criticized the report for being too liberal because it did not condemn embryo research outright, while scientists objected that it too greatly restricted biomedical research. ${ }^{65}$

Ideas similar to those of Braibant recurred in Noëlle Lenoir's June 1991 government report, which she researched and published at the request of then Prime Minister Michel Rocard. ${ }^{66}$ Lenoir, another former member of the Council of State, again stressed that ART should only be used for medical reasons and not simply to respond to the "procreative fantasies by one's self and for one's self."

French parliamentarians later compiled two additional reports. In February 1992, Franck Sérusclat, a socialist senator (un sénateur), and Bernard Bioulac, a socialist deputy (un député) in the National Assembly, submitted reports intended to inform legislators about bioethics questions. ${ }^{68}$ The parliamentarians reiterated what was beginning to become a familiar refrain in the bioethics debates: they advised that access to ART be restricted to heterosexuals. ${ }^{69}$

Following the publication and study of these reports, three bioethics laws were submitted for consideration by the French Parliament on March 25, 1992. ${ }^{70}$ An initial vote on the bioethics laws took place in the National Assembly on November 26, 1992. ${ }^{71}$ A very

64. See Conseil d'état, Sciences de la vie: de l'éthique au droit, in HISTOIRE DE LA RECHERCHE BIOMÉDICALE ET DROITS DE L'HOMME 66, 69 (1990). This report, compiled by Guy Braibant, is commonly referred to as the rapport Braibant but is officially entitled Sciences de la vie: de l'éthique au droit (Biological Sciences: From Ethics to Law).

65. See ARNOUX, supra note 10, at 318.

66. See id. Lenoir's report is entitled Aux frontières de la vie: une éthique biomédicale à la française (At the Frontiers of Life: Biomedical Ethics the French Way).

67. LENOIR, supra note 20, at 45.

68. See ARNOUX, supra note 10, at 319 .

69. See Bernard Bioulac, Rapport d'information No. 2565, Assemblée Nationale (Feb. 2, 1992); SÉRUSCLAT, supra note 1, at 36.

70. The French Parliament is made up of two houses: the National Assembly and the Senate. The National Assembly is the more powerful and dominant chamber of Parliament. It may veto bills passed by the Senate. If the Senate vetoes bills passed by the National Assembly, however, a conciliation committee made up of members of both chambers meets to work out a compromise. See IAN Derbyshire, Politics in FranCE: From Giscard to MitTERAND 1012 (1987).

71. See ARNOUX, supra note 10, at 319 . 
large majority adopted the legislative proposal addressing ART in the National Assembly: 346 deputies voted for the law; 78 voted against. ${ }^{72}$

The 1993 elections delayed a reading of the bioethics laws by both the National Assembly and the Senate until $1994 .{ }^{73}$ During the interim, Mitterand affirmed that the bioethics laws remained a priority for his administration. ${ }^{74}$ In June 1993, Mitterand's new prime minister, Edouard Balladur, asked Professor Jean-François Mattei, a pediatrician and geneticist at the Université de Marseilles, to examine the bioethics laws that had been submitted to the National Assembly in 1992. ${ }^{75}$ Mattei, a UDF (Union pour la Démocratie Française) deputy from Bouches-du-Rhônes, consequently published a third parliamentary report on November 16, 1993, written in the same vein as those published by Bioulac and Sérusclat. ${ }^{76}$ Mattei's report and his expert testimony in the National Assembly so profoundly influenced parliamentary debate that some have dubbed him the "father" of the French 1994 bioethics laws. $^{77}$

The proposed laws went back and forth between the Senate and the National Assembly. ${ }^{78}$ On January 19-20, 1994, the Senate voted on the texts adapted by the National Assembly in $1992 .{ }^{79}$ The Senate reaffirmed, as recommended by the various government reports, that ART could only be used by infertile heterosexual couples. ${ }^{80}$ The Senate also specified that couples must prove they have been together for at least two years in order to have access to ART ${ }^{81}$ For the most part, though, the Senate made few significant changes in the

72. See id. The Socialist Party endorsed the bioethics law. See id. Interestingly, members of both the Union pour la Démocratie Française (UDF), a center-right party that is opposed to state intervention, and the Rassemblement pour la République (RPR), a neo-Gaullist party that supports state intervention, both voted for the project. See id.

73. See CHARNET \& CADIEU, supra note 50, at 84.

74. See Szleper, supra note 24, at 39.

75. See CHARNET \& CADIEU, supra note 50, at 83.

76. See ARNOUX, supra note 10 , at 39 .

77. See Catherine Vincent, La brevetabilité du vivant en quête d'éthique; Un rapport parlementaire souligne les lacunes d'une directive européene sur la protection juridique des inventions biotechnologiques [The Ethics of the Patentability of Life: A Parliamentary Report Highlights the Shortcomings of a European Directive on the Legal Protection of Biotech Inventions], LE MONDE, July 4, 1996, at 23.

78. See ARNOUX, supra note 10, at 39 .

79. See CHARNET \& CADIEU, supra note 50, at $84 \mathrm{n} .222$.

80. See id. at 84.

81. See id. 
legislation. ${ }^{82}$ Again, a large degree of consensus surrounded the issue of ART and family.

The laws were then transmitted to the National Assembly in April 1994 for a vote on the amendments made by the Senate. ${ }^{83}$ The National Assembly adopted the bills and sent them once again to the Senate in May of $1994 .{ }^{84}$ During this session, the senators returned to the issue of access to ART, and they again emphasized the importance of restricting it to heterosexual couples of procreative age. ${ }^{85}$ The National Assembly and the Senate disagreed on several other points, though, such as the senators' efforts to ban embryo experimentation completely. Thus, in accordance with standard parliamentary procedure, a special committee made up of members from both chambers of the legislature met to draft a compromise for the laws. The senators ultimately agreed to allow embryo experimentation, but only within strict limits. ${ }^{86}$ The legislators' disagreement during the bioethics debates, therefore, was mainly confined to issues besides access to ART.

A few staunch opponents of the ART laws emerged in both the Senate and the National Assembly. One of the most vocal opponents of the bioethics laws in the Senate was Bernard Seillier. ${ }^{87}$ Seillier opposed the laws because he believed that no one at all should be allowed to use artificial procreative technology. ${ }^{88}$ Seillier proclaimed in an article published after the debates, "I was the only one to ask the fundamental ethical question, is it legitimate to use artificial methods in place of the natural process?"

Seillier's counterpart in the National Assembly was Christine Boutin, a UDF deputy from Yvelines. Boutin opposed the articles drafted concerning ART because she also believed that they were not conservative enough in their restriction of the use of the technology. Boutin objected to the fact that ART was becoming a commonplace

\footnotetext{
82. See id.

83. See Szleper, supra note 24 , at 39.

84. See CHARNET \& CADIEU, supra note 50, at 92.

85. See id.

86. See DERBYSHIRE, supra note 70, at 12 .

87. See Bernard Seillier, Ethique ou anti-éthique [Ethics or Anti-ethics], 5 LES PETITES AFFICHES, Dec. 14, 1994, at 149.

88. See id.

89. Id. ("[J]e fus bien seul pour soulever la question éthique préliminaire, à savoir la légitimité même de recourir à des méthodes artificielles à la place du processus naturel . ...”).
} 
"quasi natural mode of procreation." $"$ "She stated, "[ART] is not a panacea and should only be used exceptionally!... [ART] in its diverse applications, has taken on such an importance that it goes beyond its primary object: it is now the crucible of all dangers." ${ }^{.1}$ Boutin wanted to further restrict access to ART because she viewed the technology as dehumanizing: "I will say that the more one leaves behind the natural process of procreation, the more one enters the artificial, and the more one dehumanizes." 92

Despite Seillier and Boutin's vocal-but largely unsupportedopposition, the Parliament officially adopted the bioethics laws on June 23, $1994 .{ }^{93}$ On June 29, Philippe Séguin, a member of the RPR (Rassemblement pour la République) and the president of the National Assembly, transmitted the laws to the Constitutional Council (Conseil Constitutionnel), a nine-member court that judges the constitutionality of laws. ${ }^{94}$ Séguin's action highlighted the importance the French government accorded to the bioethics laws. The president of the National Assembly rarely submits a law to the Constitutional Council, and, moreover, this option is usually only used for questions of parliamentary procedure. ${ }^{95}$ In submitting the law to the Council, Séguin hoped to endow the laws with the power of a constitutional decree. ${ }^{96}$ In a letter to the president of the Council he wrote:

In consideration of the importance of these [bioethics laws] for determining the liberties and fundamental rights which proceed from the principles and rules validated by the constitution, I think they should be reviewed by the Constitutional Council to ensure that their conformity to the Constitution will never be questioned and that their value as rules of arbitration be endowed by the most appropriate court. ${ }^{97}$

90. Christine Boutin, Pour la défense de la VIE [For the Defense of Life] 42 (Pierre Téqui ed., 1993) ("un mode quasi naturel de procréation").

91. Id. ("[ART] n'est pas une panacée et qu'elle ne devrait être qu'une technique exceptionnelle! ... [ART], d'une façon générale, a pris une telle ampleur qu'elle a debordé son objectif originaire: elle est devenue le creuset de tous les dangers ....").

92. Id. ("Je dirais que plus on s'éloigne du processus naturel de la procréation, plus on entre dans une ère d'artifices, et plus on se déshumanise.").

93. See Bréhier, supra note 3, at 8.

94. See id.

95. See id.

96. See id.

97. Id. The above translates to 
The Constitutional Council's decision to ratify the bioethics laws appeared in the Journal Officiel de la République, an official publication of the French government that documents recent legislation. $^{98}$ Noëlle Lenoir, who had become a member of Constitutional Council, asserted that the French court was the only one in the world to have reviewed such general bioethics laws. ${ }^{99}$ Lauding the court's action as "creative," Lenoir praised the Constitutional Council for referring to the 1789 Declaration of the Rights of Man and Citizen to judge the constitutionality of the laws and stated that the laws were an important "protection against dangerous scientific practices." 100

As of 1991, however, ART still accounts for less than 1\% of births in France. ${ }^{101}$ Why has so much attention been focused on a technology that continues to affect only a small fraction of the entire French population? The transcripts of the French legislative debates suggest that ART has attracted so much controversy because of its potential effect on the traditional family structure. In her report to the French government, Noëlle Lenoir affirmed that "the quantitative aspect is minor. What counts above all is the fact that medically assisted procreation disrupts our traditional understanding of modes of conception and parental structures."

It has long been assumed that the only "natural" family is the traditional one headed by a heterosexual couple of procreative age. However, the new technologies make it possible for lesbian couples and post-menopausal women to bear genetically related children. The reality of these possibilities exposes seemingly fundamental assumptions about the "natural" family as just that: assumptions, not absolutes imposed by nature. Professor Martha Minow explains that the practices of artificial insemination and in vitro fertilization

Eu égard à la portée déterminante de ces textes pour la mise en œuvre de libertés et de droits fondamentaux qui procèdent de principes et de règles à valeur constitutionnelle, j'éstime devoir les soumettre au Conseil constitutionnel afin que leur conformité à la Constitution ne puisse être affectée d'aucune incertitude et que puisse être consacrée par les voies les plus appropriées la valeur de réference des règles principales qu'ils édictent.

98. See Lenoir, supra note 4 , at 1261.

99. See id.

100. Id.

101. See LENOIR, supra note 20, at 31.

102. Id. ("L'aspect quantitatif est mineur. Ce qui compte surtout, c'est le fait que les procréations médicalement assistées boulversent nos reprèsentations traditionnelles des modes de conception et des structures de la parenté."). 
"expose social and cultural choices involved in what the law had previously treated as natural." ${ }^{, 103}$ As I will explore further in Parts II and III, this repeated discussion of the relationship between family, nature, and society marks the re-emergence of central Enlightenment themes in the contemporary biomedical ethics debates in France.

\section{FAMILY, SOCIETY, AND ARTIFICIAL REPRODUCTIVE TECHNOLOGY}

The patriarchal family prevalent during the eighteenth century hardly resembles the widely diverse family units of the twentieth and twenty-first centuries. ${ }^{104}$ In fact, the growing number of families made up of unmarried couples or single parents has led French sociologists to ask whether we are even capable of defining the contemporary family. ${ }^{105}$ Nonetheless, these two different time periods share a fundamental view of the role of the family: in both times, the wellbeing and the stability of the family unit are perceived to be inextricably linked to the well-being and stability of society as a whole.

This part will explore how the writings of Jean-Jacques Rousseau about the importance of proper reproduction and child-rearing methods helped to establish French society's focus on the close interrelationship between the well-being of the family and society during the Enlightenment. ${ }^{106}$ Analysis of the family-centered rhetoric the legislators used during the bioethics debates suggests that Rousseau's ideas continue to circulate in a transmuted form in France. But whereas Rousseau depicted the family as a privileged unit of social reform and change, the legislators attempted to use the family as a bulwark against the disintegration of traditional social norms.

\section{A. Politicizing the Family in the Eighteenth Century}

Historical records indicate that prior to the seventeenth and eighteenth centuries, the birth of children was viewed primarily as a

103. Martha Minow, Lecture at Harvard University (May 1997) (transcript on file with the Duke Law Journal).

104. See Louis Roussel, peut-on donner une définition de la famille?, in LA FAMILLE ET LES FAMILLES: QUELLES IDENTITES AUJOURD'HUi? 13, 16-17 (Robert Steichen \& Guy de Villers eds., Academia Bruylant 1990) (outlining the historical changes in family structure).

105. See id.

106. See id. 
means of legitimating a marriage. ${ }^{107}$ But beginning in the seventeenth century, historians of the family observed a dramatic change in this attitude: "The family ceased to be solely an institution of private rights for the transmission of objects and family name, it assumed a moral and spiritual function, it formed bodies and souls." this time, aristocratic and bourgeois families seemed to rediscover the child and began to accord him an increasingly bigger role, until finally the family centered around the child. ${ }^{109}$ As children became more of a part of the every day life of French families, the family came to be viewed as a sort of "small society."

In the eighteenth century, close relationships between parents and their children came to be highly valued. As French historian of the family André Burguière explains:

In the eighteenth century, both the relaxation of religious control and the contagious effect of an ideology, daughter of the "Enlightenment," favorable to the autonomy of the individual and the pursuit of pleasure and worldly happiness expressed in an outpouring of sentiment gave rise to a permissive climate for sexuality and proposed marriage for love as a social ideal. ${ }^{111}$

The child became the focus of this new Enlightenment cult of sentiment, the key person in the familial network. ${ }^{112}$ Enlightenment thinkers valued knowledge and reason and viewed the child as the

107. See André Burguière \& François Lebrun, Le prêtre, le prince et la famille, in HisTOIRE DE LA FAMILLE [HISTORY OF THE FAMILY] 93, 96 (André Burguière et al. eds., 1986).

108. PhILliPE ARIÈs, L'ENFANT ET LA FAMILLE SOUS L'ANCIEN RÉGIME [THE CHILD AND FAMILY LIFE DURING THE ANCIEN RÉGIME] 464 (1960).

109. See Paul Servais, Les Familles Européennes et l'histoire: à la recherche des invariances à la découverte des contingences, in LA FAMILLE ET LES FAMILLES: QUELLE IDENTITÉ AUJOURD'HUI?, supra note 104, at 39 ("La famille aristocratique et bourgeoise, entre le XVIe et le XXe siècle, redécouvre l'enfant, lui accorde une place de plus en plus grande et finit par se centrer sur lui." This translates as: "Between the sixteenth and the twentieth century, aristocratic and middle-class families rediscovered the child, gave him a larger and larger role, and finally centered themselves around him.").

110. ARIÈs, supra note 108, at 457.

111. Burguière \& Lebrun, supra note 107, at 113 ("Au XVIIIè siècle, le relâchement du contrôle religieux et l'effet de contagion d'une idéologie, fille des $<<$ Lumières $>>$, favorable à l'autonomie de l'individu, à la construction d'un bonheur terrestre fondé sur l'effusion sentimentale et le plaisir, fait resurgir un climat permissif à l'égard de la sexualité et propose le mariage d'amour comme idéal social.").

112. See Michel Vovelle, Preface to L’enfant, LA FAMILle, et LA RÉVolution FRANÇAISE 18 (Marie Françoise Levy \& Olivier Orban eds., 1990) ("[P]olitique volontaire ... désigne l'enfant dans une place nouvelle—comme le personnage essentiel du réseau familial."). 
future beneficiary of this knowledge. ${ }^{113}$ These developments led historian Philippe Ariès to comment that during the Enlightenment, "it was not individualism that triumphed, it was the family."

The reorganization of the French family around intimacy and child-rearing was accelerated by the rise of a print culture in the 1750s. ${ }^{115}$ New systems of printing and distribution enabled the widespread publication of domestically oriented manuals and novels. ${ }^{116}$ The individuals promoting the new "familialism" included jurists, physicians, philosophers, and novelists. ${ }^{117}$ The new family household arrangements suggested by these writings "constituted an attempt to reorganize and regulate a plurality of practices thriving in various regions, social castes, and classes in the eighteenth and nineteenth centuries." 118 For example, sovereigns set legislative obstacles to divorce and attempted to use the family "as an essential link in the ever more necessary surveillance of individuals."

Rousseau was a particularly important promoter of the new focus on the importance of the family to the well-being of society during the Enlightenment. ${ }^{120}$ Michel Verelle comments, "Was there not, on the eve of the Revolution, a kind of agreement around a new vision of the family, around a new sensibility to the family, of which a diffuse but widespread Rousseauism would have been the expression?" 121 For example, Rousseau's Émile (1762) focused

113. See Servais, supra note 109 , at 39 ("La responsabilité éducative de la famille, déjà présente dans l'Antiquité, a été retrouvée, mais... [cette] fois, c'est dans l'intérêt de l'enfant ....").

114. ARIÈs, supra note 108 , at 461 ("Ce n'est pas l'individualisme qui a gagné, c'est la famille.").

115. See Roddey Reid, Families in Jeopardy: Regulating the Social Body in FRANCE, 1750-1910, at 28 (1993).

116. See id.

117. See id.

118. Id. at 29 .

119. Burguière \& Lebrun, supra note 107, at 110 ("comme un relais essentiel dans la surveillance de plus en plus nécessaire des individus").

120. Mira Morgenstern states that Rousseau's

[c]ontemporary liberal political thought of the 17th and 18th centuries, on the other hand, tended to see the private sphere as completely separate from the public realm; hence irrelevant to it and therefore unimportant. Rousseau is likewise unsympathetic to this view, demonstrating the interconnectedness between the private and public realms and consequently the immense political significance of the quotidian.

Mira Morgenstern, Rousseau for the Twentieth Century: Interpretations of the Family, in REAding LA Nouvelle HÉloḮse TOdAy 223, 231 n.18 (Ourida Mostefai ed., 1993).

121. Vovelle, supra note 112, at 16 ("N'y avait-il pas, à la veille de la Révolution, une sorte de rencontre autour d'une image nouvelle de la famille, autour d'une sensibilité nouvelle à la 
entirely on the education of children and their introduction to society. ${ }^{122}$ Rousseau questioned the validity of various traditions in child care in Émile. ${ }^{123}$ He decried the practice of swaddling, and he even went so far as to suggest that religious instruction be withheld from children until adolescence. ${ }^{124}$ Rousseau also strongly supported breast-feeding because he thought the practice would help develop the affective relations between mother and child. ${ }^{125}$ In fact, Émile was directly responsible for the breast-feeding fashion that took hold of upper-class households during the Restoration. ${ }^{126}$

Rousseau capitalized on the political potential of familial discourse in his novels because he hoped social values could be reformed by means of the reorganization of the family. In Émile, Rousseau outlined the project of reform he envisioned for the household:

If women would only deign to nurse their children, morals would reform of themselves, sentiments of nature would awaken in every heart, the State would become populated again; this first point, this point alone [subsumes] all the others. The attraction of domestic life is the best antidote to bad morals. Thus, the mere correction of these excesses would result in a general reformation; soon nature would reassert its rights. Once women become mothers again, men will soon become again fathers and husbands. ${ }^{127}$

Rousseau again explored the link between the moral well-being of society and the well-being of the family in the immensely successful epistolary novel Julie ou La Nouvelle Héloüse (1761). ${ }^{128}$ As noted

\footnotetext{
famille dont un rousseauisme diffus mais diffusé aussi aurait été l'expression?").

122. See JeAn-Jacques Rousseau, Emilie ou De L'Éducation passim (J.M. Gallanar ed., 1762).

123. See id.

124. See id.

125. See id.

126. See Burguière \& Lebrun, supra note 107, at 143; see also REID, supra note 115, at 42. Reid states that this breast-feeding fashion actually had profound political implications and has been described as a "conscious" and "well-timed" political act:

"The aristocracy appropriated domesticity as a class ideal in an effort to answer middle-class criticism of the nobility and, consequently, to forestall the political triumph of the bourgeoisie during the Restoration. Domesticity ... was fundamental to the aristocracy's program for class preservation and political survival."

Id. (quoting Margaret H. Darrow, French Noblewomen \& the New Domesticity, 1750-1850, 5 FEMINIST STUD. 41, 42 (1971)).

127. REID, supra note 115, at 26-27 (quoting JEAN-JACQUES RousSEAU, ÉMILE OU DE L'ÉDUCATION 258 (Gallimand 1969)).

128. Between 1778 and 1978, fifty-five different editions of La Nouvelle Héloüse were
} 
historian of the Enlightenment Ernst Cassirer remarked, "All the second half of the Nouvelle Héloüse is dedicated to this vindication of the family, which is considered to be the guardian and the protector of all human virtues." ${ }^{129}$ Rousseau explicitly established a link between the public and domestic spheres at the very outset of $L a$ Nouvelle Héloüse when he wrote in the second preface, "If there is to be a reform in public morals, it must start in the domestic morals; and this will ultimately depend on fathers and mothers."

But why this focus on the family? And what exactly would Rousseau like to see transformed in society? The article Famille in the Enlightenment Encyclopédie suggests an answer to the first query. ${ }^{131}$ This article defines the family "as a 'domestic society' established by nature." ${ }^{132}$ Harvard Professor of Romance Languages and Literature Christie McDonald explains that during the Enlightenment the family was thought to serve "as the foundation of national society because a people or nation 'is simply a composite of several families." ${ }^{133}$ Rousseau expressed this view in Du Contrat social:

The most ancient of all societies, and the only natural one, is that of the family.... The family is therefore, if you wish, the first model of political societies. The leader is the image of the father, the people are the image of the children; and since all are born equal and free, they only alienate their freedom for their own utility. ${ }^{134}$

published. This figure does not include works published in euvres complètes and unofficial editions of the book. See Raymond Trousson, La Nouvelle Héloïse devant la critique et l'histoire littéraires au XIXe siecle, in READING LA NOUVELlE HÉlOḮsE TODAY, supra note 120, at 12.

129. ERnst CASSIRER, Le Problème JeAn-JacQues Rousseau 84 (1987) ("Toute la deuxième partie de La Nouvelle Héloüse est consacrée à cette apologie de la famille, considérée comme la gardienne et la protectrice de toutes les vertus humaines.").

130. RousSEAU, supra note 2, at 751 ("S'il y a quelque reforme à tenter dans les mœurs publiques, c'est par les moeurs domestiques qu'elle doit commencer; et cela dépend absoluments des pères et mères.").

131. See Christie McDonald, The Changing Discourse on the Family and State: The Case of Bastardy, in STUdies ON Voltaire AND THE EIGHTEENTH CENTURY 1684 (Murray G.H. Pittock ed., 1992).

132. Id.

133. Id. at $1684-85$.

134. Jean-JacQues Rousseau, On the Social Contract 132, in 4 The Collected Writings of Rousseau (Roger D. Masters \& Christopher Kelly eds., Roger D. Masters et al. trans., University Press of New England 1994) [hereinafter RoussEAU, SOCIAL CONTRACT]. The original French reads:

La plus ancienne de toutes les sociétés et la seule naturelle est celle de la famille...

La famille est donc si l'on veut le premier modèle des sociétés politiques; le chef est 
For Rousseau, the family is the prototype of the state. ${ }^{135}$ While Rousseau did not consider the family to be the exact equivalent of the state ${ }^{136}$ he did believe that, as the basic unit of society, the family could act as a model for political society. Rousseau seemed to believe that the family unit, as the original (and the only "natural") society, could help guide widespread social reform. Rousseau hoped to signal political change through familial discourse, and therefore he promoted reform of the family in novels like Émile and La Nouvelle Héloïse, in order to create a model for political change on a larger scale. He incorporated the family into political discourse as a means of encouraging reform of the public sphere.

But to what end did Rousseau inscribe political rhetoric in discourse about the family? Literary historian Roddey Reid answers that eighteenth-century literature such as Rousseau's "helped produce and circulate in turn a new discourse of 'family' that worked to dismantle the absolutist sphere of political representations and to inscribe a new sense of national community structured by the norms and sensibility of domesticity." 137 To this end, Rousseau created several different family models in La Nouvelle Héloüse whose structure and function (or rather malfunction) were intended to critique the legitimacy of the absolutist Ancien Régime government.

For instance, in La Nouvelle Héloïse, Rousseau described the life of the autocratic d'Étange family in very critical terms. The head of the d'Étange family, the Baron d'Étange, behaves like a stereotypical Ancien Régime aristocrat who makes decisions "according to his notion of what is due to his class and social status." ${ }^{138}$ When the Baron's daughter, Julie, falls in love with her tutor, Saint-Preux, the Baron forbids her to marry him because he is not her social equal. Rousseau, through the character of Lord Edouard Bomston, seems to lament both the cruelty of the Baron's behavior and the dictates of Ancien Régime politics when he writes:

l'image du père, le peuple est l'image des enfans, et tous étant nés égaux et libres n'aliènent leur liberté que pour leur utilité.

Rousseau, DU CONTRAT SOCIAL OU PRINCIPES DU DROIT POLITIQUE 175-76 (Constant Bouquin ed., Les Editions du Cheval Ailé 1947) [hereinafter RousseAu, Du CONTRAT SOCIAL].

135. See Melissa A. Butler, Family and the State in the Works of J.J. Rousseau, in STUDIES ON VOLTAIRE AND THE EIGHTEENTH CENTURY, supra note 131, at 1681-82.

136. See McDonald, supra note 131, at 1684.

137. REID, supra note 115, at 103.

138. Morgenstern, supra note 120, at 227. 
Let men rank according to their merit; and let those hearts be united that are objects of each other's choice. This is what the good order of society requires; those who would confine it to birth or riches, are the real disturbers of that order; and ought to be rendered odious to the public, or punished as enemies to society. ${ }^{139}$

Rousseau was strongly critical of any form of governmentgovernment of the family or of society-that based decisions only upon social rank and required the complete suppression of individual desires. ${ }^{140}$

Rousseau again united family and politics in his description of the Wolmar family's life at Clarens. Rousseau's depiction of life at Clarens can be interpreted as an implicit attack on despotism because, like a despot, Wolmar (the man Julie's father forces her to marry instead of Saint-Preux) controls and observes everything. Julie writes to her friend and cousin Claire that, "M. Wolmar's chief delight is observation ... I have imagined sometimes that he took particular notice of me during these conversations ...."141 Moreover, Saint-Preux's letters suggest that life at Clarens is extremely ordered and controlled because the workers at Clarens "have observers that animate and watch them."142

This account of family life at Clarens closely resembles the despotic states Rousseau denounced in Du Contrat social:

It will be said that the despot guarantees civil tranquillity to his subjects. ... What have they gained, if this tranquillity is one of their miseries? Life is tranquil in jail cells, too. Is that reason enough to like them? The Greeks lived tranquilly shut up in the Cyclop's [sic] cave as they awaited their turn to be devoured. ${ }^{143}$

139. JeAn-JACQues Rousseau, 1 Eloisa 325 (Kenrick trans., 1990) [hereinafter RousSEAU, EloISA]; RousseAu, supra note 2, at 170 ("Que le rang se règle par le mérite, et l'union des cœurs par leur choix, voilà le véritable ordre social; ceux qui le règlent par la naissance ou par les richesses sont les vrais perturbateurs de cet ordre; ce sont ceux-la qu'il faut décrier ou punir.").

140. See Rousseau, 1 Eloisa, supra note 139, at 325; Rousseau, supra note 2, at 170.

141. RousseAU, 1 EloISA, supra note 139, at 290; RousSEAU, supra note 2, at 349-50 ("Le plus grand goût de M.Wolmar est d'observer.... J'ai cru remarquer quelquefois qu'il m'observait durant ces entretiens ....").

142. RousSEAU, supra note 2, at 425 ("ont des surveillants qui les animent et les observent").

143. ROUSSEAU, SOCIAL CONTRACT, supra note 134, at 134. Rousseau wrote:

On dira que le despote assure à ses sujets la tranquillité civile .... Qu'y gagnent-ils, si cette tranquillité même est une de leurs misères? On vit tranquille aussi dans les cachots; en est-ce assez pour s'y trouver bien? Les Grecs enfermés dans l'antre du Cyclope y vivaient tranquilles, en attendant que leur tour vint d'être dévorés. 
Similarly, Wolmar's obsession with order precludes the freedom and happiness of those under his care. Julie states, "[E]verything around me gives me cause of content, and yet I am not contented. A secret languor steals into the bottom of my heart: I find it puffed up and void ...." ${ }^{144}$ Julie desired order and found it in the confines of Wolmar's despotic arms, but she comes to understand that order is not an absolute sign of legitimacy. It is only when Julie is on her deathbed after contracting a serious illness that she finally finds happiness and peace. Julie's discontentment at Clarens can be interpreted as an implicit critique of any family-or society-that attempts to justify itself with the promise of order. One is not fully human in a despotic family or society because one is forced to live in chains.

Rousseau's writings helped to powerfully reshape how the French conceived of the relationship between family and society:

In his approach to the political significance of daily life Rousseau distinguishes himself from both his classical and liberal precursors. Unlike Plato, who viewed the structures of daily life as inherently antithetical to the higher consciousness required for the attainment of the just political State, Rousseau demonstrates the positive contributions of everyday structures like the family to political life. Contemporary liberal political thought of the 17th and 18th centuries, on the other hand, tended to see the private sphere as completely separate from the public realm; hence irrelevant to it and therefore unimportant. Rousseau is likewise unsympathetic to this view, demonstrating the interconnectedness between the private and public realms and consequently the immense political significance of the quotidian. ${ }^{145}$

Thus, by inscribing a critique of Ancien Régime forms of government in the family-centered discourse of the La Nouvelle Héloïse, Rousseau created a strong link between the familial and the political. In so doing, Rousseau helped establish a fundamental view of the family in French society: discourse about the family was to play an important role in the reform of society.

RouSSEAU, DU CONTRAT SOCIAL, supra note 134, at 182.

144. RousseaU, 1 EloisA, supra note 139, at 194; RousSEAU, supra note 2, at 622 ("Je ne vois partout que sujets de contentement, et je ne suis pas contente; une langueur secrète s'insinue au fond de mon cœur; je le sens vide et gonflé ....”).

145. Morgenstern, supra note 120 , at 231. 


\section{B. Reformulating Rousseau's Ideas in the Twentieth Century}

A comparison of Rousseau's rhetoric about the family with that used by the French legislators in the 1994 French bioethics debates suggests that Rousseau's ideas about the interrelationship between the well-being of the family and society continue to be very influential. ${ }^{146}$ The wide availability of ART during the twentieth century has again propelled Rousseau-esque concerns with the interrelationship between private and public spheres, between family and society, to the forefront of the public consciousness. The French legislators drafted the bioethics laws as a means of preventing technology from destabilizing and reshaping socio-cultural norms:

Recent advances in reproductive technologies have put into question the belief (whether implicit or explicit) that biology, as a teleological process, can hold cultural chaos in abeyance. The doors have been opened wide as the definition and status of mother, father, and child have all been deeply questioned.... There is a sense that the threat to the family signals a disintegration of order, leaving the contemporary sense of self bereft of a discourse that can represent universal order. ${ }^{147}$

Confronted with technologies that might further accelerate the disintegration of bi-parental heterosexual family unit, the legislators drafted the bioethics laws as a means of re-establishing a sense of "order" in the face of "cultural chaos." Close analysis of the transcripts of the legislative debates reveals that the legislators restricted access to ART as a means of protecting French society from the disruptive effects and "disintegration of order" they believed would accompany dramatic changes in the family structure. ${ }^{148}$

As discussed in Part I, the French bioethics laws restricted access to ART to heterosexual couples of procreative age. The legislators appeared troubled by the possibility that ART could be used to enable homosexuals, post-menopausal women, and virgins to create children. ${ }^{149}$ In part, the legislators restricted access to ART because

146. See id. at 235 (noting that "two hundred years after Rousseau first remarked on the importance of the family to the resolution of crucial political issues, the family still remains at the center of political debate").

147. Christie McDonald, Modern Tales of Anxiety, 43 Diogenes 69, 69 (1995).

148. See Declan Butler, Bioethics Panels May Be Threat to Public Debate on Research, NAture, Jan. 25, 1996, at 289 (stating that, as Phillipe Lazar explains, "the demand for bioethics legislation . . . is symptomatic of society's fear of change").

149. See LENOIR, supra note 20, at 43 (citing the artificial insemination of virgins at a clinic 
they did not want the children to be received into an unstable environment that might be detrimental for their future psychological well-being. Charnet and Cadieu, two contemporary analysts of the French bioethics debates, explain that:

For the members of the parliament, the setting of boundaries on medical practice was part of an even more fundamental obligation to ensure respect for values that provide the basis for our society; that is to say the family, "founding cell in which the child learns about social dimension, exchange, dialogue, generosity and availability for others."

In addition to the well-being of the children themselves, another powerful impetus for these restrictions was the legislators' apparent concern that the sudden influx of new reproductive capabilities would destabilize the entire French social system. ${ }^{151}$ It was believed this destabilization would occur because France's system of laws is predicated upon the predominance of the more traditional biparental, heterosexual family unit. ${ }^{152}$ For example, current legal means of adjudicating paternity could be disrupted because the woman who provides the ova for an ART procedure might not be the same one in whom gestation occurs. ${ }^{153}$ There were additional concerns about adjudicating paternity because the sperm used for an ART procedure can be that of the husband, a partner (concubin), an anonymous donor, or a dead spouse. ${ }^{154}$ Others expressed alarm at the fact that in vitro fertilization might be used to disrupt the normal genealogical development of a family because ova can remain frozen for long periods of time before being implanted in the uterus. ${ }^{155}$

President Mitterand summarized the concerns of the French government about ART at the first meeting of the CCNE (France's

in Birmingham as a "good example of what could happen in France" without controls) ("La révélation de la pratique de l'insémination de femmes vierges par un centre privé de Birmingham en Angleterre, est un bon exemple de ce qui pourrait arriver en France.").

150. Charnet \& CAdieu, supra note 50, at 87. The original text reads: "Pour les parlementaires, cet encadrement de la pratique médicale participe d'une autre exigence plus fondamentale encore: veiller au respect des valeurs qui fondent notre société, en l'occurence, la famille, <<cellule fondatrice dans laquelle le petit homme apprend sa dimension sociale, l'échange, le dialogue, la générosité, la présence aux autres.>>"

151. See ARNOUX, supra note 10, at 475 .

152. See id.

153. See id.

154. See id.

155. See BAUdOUIN \& LABRUSSE-RIOU, supra note 12, at 217. 
national bioethics committee) when he stated: "Who is the father? Who is the mother? The right [to parenthood] is no longer clear-cut, with in vitro fertilization now possible." ${ }^{, 156}$ Mitterand went on to say that ART

"disturbs one of the constitutive relations of our identity which underlies the family and society.... Some terrible questions [arise] .... Your committee of ethics must be the place for dialogue, confrontation, reflection, and advice. It could be a place for mediating between the collective sensibility and the intervention of the public authorities."

From the very outset, one of the fundamental tasks set for the national bioethics committee was the resolution of issues related to the interaction between family, society, and ART.

The idea that the familial permutations made possible by ART could cause a contingent destabilization of society was manifest in the transcripts of the 1994 French legislative debates themselves. For example, Jean-François Mattei, the so-called father of the bioethics laws, lamented during a session of the National Assembly:

[Because of ART] [o]ne could witness the birth of children deliberately conceived without a father, with two fathers and one mother if the donor was not anonymous, with two mothers but no father in the case of a lesbian couple. So, in brief, with in vitro fertilization we could have children with five parents. Is this the family model that we wish to see developed in our society? Evidently, no! ${ }^{158}$

As suggested by Charnet and Cadieu, Mattei seemed to fear that French society would be changed for the worse should the government permit use of ART to restructure family norms. ${ }^{159}$

156. Ambroselli, supra note 54, at 20 (quoting President Mitterand's statement at the first working meeting of the CCNE in December of 1983).

157. Id.

158. 11 LA BIOÉTHIQUe DEVANT LE PARLEMENT FRANÇAIS: 1988-1994, at 2753 (Tristan Mage ed., 1994) [hereinafter Debates]. Translated, this reads:

On pourrait alors ... assister à la naissance d'enfants conçus délibérément, orphelins de père, avec deux pères et une mère si le donneur n'était pas anonyme, avec deux mères mais pas de père dans le cas de couples de femmes. Bref, avec la fécondation in vitro, nous pourrions avoir des enfants ayant cinq parents différents. Est-ce le modèle familial que nous souhaitons voir se développer dans notre société? Non, à l'évidence!

Id.

159. See CHARNET \& CADIEU, supra note 50 , at 86-88. 
Mattei's comments reveal a belief that a multiplication of alternative modes of family will somehow profoundly disturb French society. Thus, much like Rousseau, Mattei seems to perceive an intimate link between family and society.

Deputy Elisabeth Hubert appeared to share this viewpoint in her remarks in a National Assembly session:

Not to legislate is to accept situations that we condemn because of our culture, of our sense of values, of our vision of man; it is, tomorrow and forever, to see newspaper headlines about a woman demanding artificial insemination, about a woman well past the physiological age for childbearing demanding [ART] .... It is to answer those problems that these [legislative] texts have been drafted. ${ }^{160}$

Like Mattei, Hubert hoped to promote, by means of legislation, a certain idea of family that marginalized groups that she viewed as a threat to French culture. The connection between family and society Rousseau envisioned, it appears, remains a potent idea in French culture.

As discussed in Part I, such concerns were perhaps most fervently expressed by UDF Deputy Christine Boutin and Senator Bernard Seillier. ${ }^{161}$ These two legislators wanted to institute bioethics laws that blocked access to ART altogether because of the dire consequences they believed use of "unnatural" procreative processes would have on the moral fabric of French society. For instance, Boutin declared that ART was the "crucible of all dangers," 162 and Seillier questioned the ethics of using an artificial procreative process rather than the "natural" one. ${ }^{163}$

To help prevent these new reproductive capabilities from disrupting French society, the French legislature specified exactly which sorts of couples could legally benefit from ART. As discussed

160. Debates, supra note 158, at 2772. In French, this reads:

$\mathrm{Ne}$ pas légiférer, c'est accepter des situations que nous condamnons en raison de notre culture, de notre sense des valeurs, de notre vision de l'homme; c'est, demains voir encore et toujours les journaux faire la $<<$ une $>>$ sur une femme demandant une insémination artificielle, sur une femme ayant depuis longtemps depassé l'âge physiologique pour procréer reclamant une PMA.... C'est notamment pour Id. répondre à ces problèmes que ces textes ont été élaborés.

161. See supra notes $87-92$ and accompanying text.

162. Boutin, supra note 90, at 42 ("le creuset de tous les dangers").

163. See Seillier, supra note 87 , at 149 ("I was the only one to ask the fundamental ethical question, is it legitimate to use artificial methods in place of the natural process?"). 
in Part I, the 1994 bioethics laws provide: "The man and woman forming the couple must be alive, of procreative age, married or able to prove that they have lived together for at least two years and have consented to the transfer of embryos and insemination." ${ }^{164}$

This restriction of access to ART promotes the traditional biparental, heterosexual norm and implicitly denounces the promulgation of other less traditional family models. As Mattei described the legislation, "We have redefined the familial environment desirable to receive a child." 165

Thus, implicit in the legal text and the transcripts of the bioethics debates is a sense that the legislators wanted to slow down the possible social changes signaled by unrestricted use of biomedical technology. Headlines about women who have children without sexual partners or women who have children at age sixty represented, in the minds of the French legislators, a move towards a state of social and "reproductive anarchy." The French legislators designed a legal text that attempts to hold "cultural chaos in abeyance" by restricting access to the new reproductive technologies.

\section{THE CONCEPT OF NATURE IN THE ENLIGHTENMENT AND THE 1994 FRENCH BIOETHICS DEBATES}

In order to legitimize restricting access to ART, the French legislators also appealed to another important Enlightenment theme: nature. The French legislators appealed to the concept of nature as an ultimate ethical arbiter between the possible and the permissible in the 1994 bioethics debates. ${ }^{166}$ It was in the name of "nature" and the "natural" that the French legislature limited ART access to sterile heterosexual couples of procreative age. Artificial insemination of homosexual or post-menopausal women was condemned as "unnatural" because equivalent modes of procreation were not to be found in "nature"; i.e., in the world pre-existing the advent of ART. ${ }^{167}$

164. Law No. 94-654 of July 29, 1994, J.O., July 30, 1994, p. 11,062; D.S.L. 1994, 29, 411 ("L'homme et la femme formant le couple doivent être vivants, en âge de procréer, mariés ou en mesure d'apporter la preuve d'une vie commune d'au moins deux ans et consentants préalablement au transfert des embryons où à l'insémination.").

165. Debates, supra note 158, at 2757 ("[N]ous avons redéfini le cadre familial souhaitable pour accueillir l'enfant.").

166. See infra Part III.B.

167. Anne Fagot-Largeault, a member of the Comité Consultatif National d'Éthique (CCNE), France's national bioethics committee, stated, "But ethics includes an irreducible element of naturalism because it is the facts that select the objectively good norms." Fagot- 
The legislators, therefore, hoped to find an objective ethical order in nature that would guide their bioethics deliberations, and thus they expressly derived "ought" from "is.",168

This part of the Note will argue that this mode of argumentation can be understood as a selective and transforming interpretation of Enlightenment ideas about nature and its link to ethics and the social order. The legislators used words that echo Enlightenment rhetoric, but they restricted and changed the meaning of Enlightenment terms. ${ }^{169}$ Rousseau, among other Enlightenment thinkers, envisioned a highly complex and dynamic relationship between nature and culture that was much reduced in the contemporary bioethics debates. ${ }^{170}$

A rereading of Rousseau's novels facilitates a better understanding and critique of the legislators' reliance on a static concept of the "natural" to restrict access to ART. ${ }^{171}$ To control unwanted effects of technology on social norms, the legislators defined nature in a limited way that, as Rousseau suggested over two

Largeault, supra note 51, at 218 ("Mais l'éthique inclut un élément irréductible de naturalisme, parce que ce sont les faits qui selectionnent les normes objectivement bonnes.").

168. See Michael J. Reiss \& Roger Straughan, Improving Nature? The Science AND ETHICS OF GENETIC ENGINEERING 63 (1996).

169. See, e.g., Jean Starobinski, Preface to ERnSt CASSIRER, LE PROBLEME JEAN-JACQUES RousseAU xix (Marc B. de Launay trans., 1987) (discussing the existence of "deformed echoes" (<<échoes déformés >>) of Enlightenment ideas in contemporary society).

170. For instance, Rousseau used the term "nature" to refer to a multitude of ideas, including "the physical environment, the living force in the world and in a person, what is original or inherent or spontaneous, what is manifest and what is potential." JOHN HOPE MASON, THE INDISPENSABLE ROUSSEAU 260 n.* (1979). Thus, for Rousseau, the passage from nature to ethics involved a dynamic interplay between the exterior world and man's inner nature, his inner being. See id.

171. The view of nature as a relatively static entity has also been challenged in the recent scholarly literature on environmental law. Jonathan Weiner's BEAK OF THE FINCH makes a "bold call for a new metaphor of nature" based on Darwinian theories of natural selection. Jonathan Baert Wiener, Law and the New Ecology: Evolution, Categories and Consequences, 22 ECOLOGY L.Q. 325, 326 (1995) (reviewing JONATHAN WEINER, BEAK OF THE FINCH: A STORY OF EVOLUTION IN OUR TIME (1994)). Wiener argues that the development of environmental law is hindered by the predominant view of nature as a static entity. See id. Wiener advocates a movement away from viewing nature as a "Kodachrome still-life" and towards viewing it as a "moving picture show ... continually changing and complex," in the words of Daniel Botkin. Id. at 329. In light of this view of nature, which is actually more in line with the vision of nature Rousseau articulated in the eighteenth century, Wiener argues that "environmental policy is and ought to be moving away from categorical rules toward weighing harms and benefits in policy judgments." Id. at 355. Similarly, this section will suggest that the French bioethics laws are categorical rules that reflect a static vision of nature and therefore are incapable of adequately addressing inherently dynamic bioethics questions. 
hundred years ago, confounds traditional views of the "right" with the natural.

\section{A. Enlightenment Concepts of Nature: Laying the Intellectual Groundwork for the Contemporary Bioethics Debates}

Defining the Enlightenment concept of nature precisely is difficult because nature represented many different ideas for different philosophers. During the Enlightenment, nature was associated with numerous metaphors, including the images of a benevolent mother, an ever-faithful servant, and even a treacherous enemy. ${ }^{172}$ But whether they conceived of man's relationship with nature as antagonistic or collaborative, the Enlightenment philosophers agreed that the "relation was intimate, inescapable, and exclusive." "173 Eighteenth-century philosophers tried to penetrate the "tangle of meanings clustering around "nature"" in order to establish "reliable standards for ethical and aesthetic judgements."

As God's creation, nature was a source of truth for Enlightenment philosophers. Ernst Cassirer commented, "[T]ruth is revealed not in God's word but in his work; it is not based on the testimony of Scripture or tradition but is visible to us [in nature] at all times." ${ }^{, 175}$ Enlightenment philosophers attempted to derive standards of "beauty and conduct" from nature.$^{176}$ For some, nature represented a rationality and order that was directly accessible to experience. As Asher Horowitz explains:

All human and divine authority could, in the mind of the Enlightenment, be replaced by the ultimate authority of unmediated experience. Nature itself, in its observable and precisely describable order and regularity, would henceforth be the ultimate and only source of truth and authority. ${ }^{177}$

Enlightenment philosophers believed that nature provided a set of a priori norms, an immanent and ultimate standard- "standards that are immanent in the process of living matter itself." "Thus, the

172. See 2 Peter Gay, The EnLightenment: An Interpretation 160 (1969).

173. Id.

174. Id. at 161.

175. ERnst Cassirer, The Philosophy of the Enlightenment 43 (Fritz C.A. Koelin

\& James P. Pettegrove trans., Princeton University Press 1951) (1932).

176. 2 GAY, supra note 172 , at 160 .

177. ASHER HOROWITZ, RousSEAU, NATURE, AND History 37 (1987).

178. Id. at 32 . 
use of nature as a criterion to help distinguish between right and wrong has a long tradition in French thought.

Philosophers as different as Diderot and the Marquis de Sade referred to nature as the ultimate arbiter when deciding questions of ethics and conduct. Diderot once exclaimed, "O, Nature, everything that is good is enclosed within your breast. You are the fertile source of all truth." ${ }^{, 179}$ Diderot believed that in nature man would be able to find the answer to such questions as "What must I do?" and "Who am I?" 180 He conceived of nature as "a vast interconnected organic whole in which the steps from matter to life, from science to ethics, from observation to admiration are not merely possible but proper and indeed essential."

Even the infamous Marquis de Sade used a certain idea of nature to justify his views about society. In La Philosophie dans le boudoir (1795), Sade cited the work of eighteenth-century naturalist Buffon to reject love. He wrote, "be quick to fly from love. There is none but physical good in it, said Buffon, and as a good philosopher he exercised his reason on an understanding of nature. I repeat it, amuse yourselves; but love not at all ...." 182 Sade also justified incest and sodomy as "natural" pleasures: "[I]f nature forbade the pleasures of sodomy, the pleasures of incest, the filthy, etc. would she have allowed us to take pleasure in such things at all? It is impossible for nature to tolerate what truly outrages it.",183

179. Norbert Sclippa, La Nouvelle Héloüse et l'aristocratie, in 284 STUDIES ON VOLTAIRE AND THE EIGHTEENTH CENTURY 9, 37 (H.T. Mason ed., 1991) (quoting a line of Diderot's Entretiens sur le fils naturel, which reads, "O, Nature, tout ce qui est bien est renfermé dans ton sein! Tu es la source féconde de toutes vérités!”).

180. 2 GAY, supra note 172 , at 162 .

181. Id.

182. Marquis De SAde, Philosophy in the Bedroom, in The Complete Justine, PHILOSOPHY IN THE BEDROOM, AND OTHER WRITINGS 179, 285 (Richard Seaver \& Austryn Wainhouse trans., 1965) [hereinafter SADE, Philosophy]. The original French reads: "mais fuyez avec soin l'amour. Il n'y a de bon que son physique, disait le naturaliste Buffon, et ce n'était pas sur cela seul qu'il raisonnait en bon philosophe. Je le répète, amusez-vous; mais n'aimez point ...." MARQUIS DE SADE, LA PHILOSOPHIE DANS LE BOUdOIR 173 (Editions Gallimard 1976) (1795) [hereinafter SADE, LA PHILOSOPHIE].

183. SADE, LA PhILOSOPHIE, supra note 182, at 107 ("[S]i la nature défendait les jouissances sodomites, les jouissances incestueuses, les pollutions, etc., permettrait-elle que nous y trouvassions autant de plaisir? Il est impossible qu'elle puisse tolérer ce qui l'outrage véritablement."). See also SADE, Philosophy, supra note 182, at 237 ("[H]ad Nature condemned sodomy's pleasures, incestuous correspondences, pollutions, and so forth, would she have allowed us to find so much delight in them? That she may tolerate what outrages her is unthinkable.”). 
Furthermore, Enlightenment philosophers often referred to the idea of natural law that was secularized during the seventeenth century. Natural laws were understood in the eighteenth century to be "eternal immutable principles of morality that stand as critics of positive law." Natural law was also defined as "the set of principles that the nature of man placed in human reason, principles that therefore are part of the very nature of man and that the legislature should include in law." 185

Enlightenment thinkers believed that the foundation of justice, the social order, and the common good could be derived from these natural laws. ${ }^{186}$ As historian Peter Gay notes, Montesquieu once stated, "In vain do the civil laws make chains... natural law will always break them." 187 Articles written by Boucher D'Argis, Jaucourt, and Diderot for the Enlightenment Encyclopédie also reflected this point of view: ${ }^{188}$ "In the mirror of the state of nature the present form of the state and contemporary society are to behold their own countenances and pass judgement on themselves." century thinkers used nature as an unforgiving "mirror" to help them judge the status quo and to legitimate their ideas.

Enlightenment philosophers, however, did not necessarily promote a return to the state of nature. For instance, Peter Gay stated of Rousseau that "[t]he original state of nature... [is] ineligible as an option and unsuitable as an ideal. [Its] single use now is to hold a mirror up to society, that men may learn to despise and to reform it." ${ }^{190}$ Rousseau hoped to realize "natural" man in the political and social state. ${ }^{191}$ For Rousseau, natural man was an individual with spontaneity of emotion who lived in complete equilibrium with his surroundings. ${ }^{192}$ Paradoxically, Rousseau believed that liberty could

\footnotetext{
184. 2 GAY, supra note 172, at 457.

185. Angèle Kremer-Marietti, Droit naturel et état de nature chez Rousseau, in JEANJACQUES ROUSSEAU ET LA CRISE CONTEMPORAINE DE LA CONSCIENCE 175, 179 (1980) ("l'ensemble des principes que la nature même de l'homme a mis dans la raison humaine, qui appartiennent ainsi à la nature même de l'homme et que le législateur devrait inclure dans le droit positif").

186. See id. at 177.

187. 2 GAY, supra note 172 , at 457.

188. See id.

189. CASSIRER, supra note 175 , at 271.

190. 2 GAY, supra note 172, at 538.

191. See Jean Lacroix, La Conscience selon Rousseau, in JEAN-JACQUES RoUSSEAU ET LA CRISE CONTEMPORAINE DE LA CONSCIENCE 81, 101 (1980).

192. See Kremer-Marietti, supra note 185, at 181.
} 
only be realized in a society that established laws restricting freedom. ${ }^{193}$ In the state of nature, the weak are subjected to the strong and so it is only in a society founded on consent to the "volontée générale" that the citizen is truly free.$^{194}$ Man is truly free in such a society because he has escaped "the laws of nature, to obey another law, a law that man has authored himself." 195 A recurring theme of Rousseau's writings is that superficial observation of nature cannot produce a static set of unimpeachable ethical "rules" that can guide society. Rousseau's "thought as a whole can be seen as a fundamental challenge to any philosophy that would attempt to grasp the problems of society and politics by way of any abstract and static concept of nature." 196

Rather, Rousseau believed that one must become immersed in nature in order to become intimately sensitive to her "rhythms" and, simultaneously, more in equilibrium with one's self. Asher Horowitz explains that

the nature appealed to is not at all of the order of sense experience, which has been revealed to be, because of its variability and subjectivity, unreliable; it is of a higher order. Rousseau calls it the "divine instinct." It is an instinct that is active, forming, prehensive, and fundamentally unlike passive and receptive sensation. ${ }^{197}$

Rousseau conceived of nature as more of an active, evolving force and thus rejected the concept of a universal and permanent set of natural laws that are immediately intuitively accessible to man. He was critical of philosophers who promoted a static and immutable vision of a "system of nature.",

In fact, Rousseau's writings do not clarify exactly what he meant when he used the term nature. Rousseau "play[ed] with the word nature without precision, [and] ... [delighted] in her wealth and never agreed to be bound by one definition." ${ }^{199}$ For Rousseau, nature

193. See Jean-Jacques Rousseau, Discourse on the Origins and the Foundations of Inequality Among Men, in THE FIRST AND SECOND Discourses 101, 134 (Roger D. Masters ed., Roger D. Masters \& Judith R. Masters trans., 1964) (1755).

194. ROUSSEAU, DU CONTRAT SOCIAL, supra note 134, at 192.

195. RAMEIX, supra note 55, at 43 ("[C]ar il échappe aux lois de la nature, pour obéir à une loi, dont il est lui-même l'auteur.").

196. HorowITZ, supra note 177 , at 46 .

197. Id. at 43 .

198. CASSIRER, supra note 129, at 97 ("système de la nature").

199. MASON, supra note 170, at 260 n.* (quoting PIERRE BURGELIN, IV OEUVRES COMPLÈTES lxxxix (Pléïade 1959)). 
referred to both man's internal being and the external environment. According to Lacroix, he used the term nature to refer simultaneously to the inner nature of man (nature de l'homme) and the nature of the external world (nature comme monde exterieur) ${ }^{200}$ Both types of nature are inextricably linked in Rousseau's thinking. In Profession de foi, Rousseau wrote, "Look at nature, listen to the inner voice, has God not said everything to our eyes, to our conscience, to our judgement?"201 By observing and immersing ourselves in the nature of the exterior, we come to better hear and comprehend the nature of the interior, the conscience.

This theme is central to Rousseau's Reveries du promeneur solitaire. In this work, Rousseau discussed the happiness he derived from communing with nature on long solitary walks. Rousseau stated, "These hours of solitude and meditation are the only ones in the day during which I am fully myself and for myself, without diversion, without obstacle, and during which I can truly claim to be what nature willed." ${ }^{202}$ His exploration of nature was inextricably linked to his exploration of self; it is only in nature that he felt really in touch with his own desires. Cassirer put it thus: "Man is no longer 'face to face' with nature, nature is no longer just a spectacle that he will enjoy as a mere thinker or observer; rather man is immersed in the internal life of nature, and he obeys nature's own rhythms." ${ }^{203}$

The experiences of Julie in Rousseau's La Nouvelle Héloüse can also be interpreted as an implicit critique of any attempt to adhere too strictly to a static conception of nature's laws. Julie feared going against her father and accepting the love she felt for Saint-Preux because she believed such an action would be "unnatural." ${ }^{204}$ In her conception of the natural order, a daughter should not disobey her father. Thus, when Julie wrote to Saint-Preux to tell him she could

200. See Lacroix, supra note 191, at 96.

201. Id. at 100 ("Voyez le spectacle de la nature, écoutez la voix intérieure; Dieu n'a-t-il pas tout dit à nos yeux, à notre conscience, à notre jugement?") (quoting Rousseau)).

202. JeAn-JACQues Rousseau, The ReVEries OF THE SOlitARy WALKer 12 (Charles E. Butterworth trans., New York University Press 1979). The French translates to: "Ces heures de solitude et de méditation sont les seules de la journée où je suis pleinement moi et à moi sans diversion, sans obstacle, et où je puisse véritablement dire être ce que la nature a voulu." JEANJACQUES ROUSSEAU, LES RÊVERIES DU PROMENEUR SOltTAIRE 13 (Henri Roddier ed., Garnier Frères 1960) (1782).

203. CASSIRER, supra note 129, at 69 ("L'homme n'est plus seulement $<<$ face à $>>$ la nature, elle n'est plus pour lui un spectacle dont il jouirait, simple contemplateur et observateur, mais il est plongé dans la vie interne de cette nature, et il obéit à ses propres rythmes.").

204. See infra notes 205-06. 
not marry him, she told him that a girl who allowed passion to make her forget her blood ties was a "fille dénaturée." ${ }^{205}$ In addition, Julie refused Lord Bomston's offer of refuge in England with Saint-Preux in the name of the "laws of consanguinity and the laws of nature.", Julie sacrificed her love because she believed it to be counter to her father's will, and thus against nature. Unwilling to challenge tradition and marry a man who is not her social equal (her tutor), Julie agreed to marry Wolmar, the man selected by her father. She believed this to be the only rational and natural course of action left open to her. At the altar on her wedding day, she said, "An invisible power seemed suddenly to rectify the disorder of my affections, and to settle them according to the laws of duty and nature." ${ }^{207}$ Julie suddenly felt at peace because she believed that by obeying her father she has realigned herself with the laws of nature. ${ }^{208}$

Ultimately, though, Julie rejected the life that her limited understanding of nature and reason guided her to take. In a letter she wrote to Saint-Preux on her death bed, she proclaimed:

No, we will not part-I go but to expect you. That virtue, which separated us on earth, will unite us for ever [sic] in the mansions of the blessed. I die in that peaceful hope; too happy to purchase at the expense of my life the privilege of loving you without a crime, and of telling you so once more. ${ }^{209}$

With her final breath, she embraced the passion and love she had previously denounced in the name of nature. Julie failed to realize happiness in life because she allowed herself to be guided by an imagined and static order of nature that conformed to her experience (i.e., to the dictates of her father and society).

Rousseau rejected such a static view of nature that confounded tradition and the status quo with the "natural." Rousseau viewed nature as a dynamic force and he did not believe that natural law was

205. RoUSSEAU, supra note 2 , at 45 .

206. RousSEAU, 2 EloISA, supra note 139, at 2; RousSEAU, supra note 2, at 184 ("droits du sang et de la nature").

207. RousSEAU, 2 ElOISA, supra note 139, at 259; RouSSEAU, supra note 2, at 333 ("Une puissance inconnue sembla corriger tout à coup le désordre de mes affections et les rétablir selon la loi du devoir et de la nature.").

208. See Sclippa, supra note 179, at 39.

209. RousSEAU, 4 ElOISA, supra note 139, at 281; RousSEAU, supra note 2, at 731 ("Non, je ne te quitte pas, je vais t'attendre. La vertu qui nous sépara sur la terre nous unira dans le séjour éternel. Je meurs dans cette douce attente : trop heureuse d'acheter au prix de ma vie le droit de t'aimer toujours sans crime, et de te le dire encore une fois!"). 
immediately accessible to unaided rational intuition. ${ }^{210}$ In the Discourse on the Origins and Foundations of Inequality (1755) Rousseau stated that philosophers caught in this trap "have all felt the necessity of going back to the state of nature, but none of them has reached it." 211 According to Rousseau, the philosophers of natural law who hold too strictly to the dictates of nature are

in the habit of abstracting the content of natural law from the behaviour of men in civil society, attributing the rationality they imagine they see there to an atemporal cognitive faculty and reconstructing the relations among men in such a way that nature turns out to correspond to those types of relations they would prefer to see in existence. The nature that they oppose to various forms of artifice thus turns out to be equally artificial and arbitrary.... ${ }^{212}$

Rousseau realized that the "natural laws" referred to as incontrovertible by some philosophers are, in fact, subjective laws that they have developed from observations of their own society. As Kremer-Marietti remarked, "Rousseau's originality consists in his shrewd suspicion that the meaning of a concept depends on the cultural context and has nothing to do with nature." 213 Rousseau specifically criticized Thomas Hobbes on these grounds in the Discourse on the Origins and Foundations of Inequality. ${ }^{214}$ Rousseau asserted that the war-like state of nature described by Hobbes is in fact an image falsely derived from his observation of the then-present state of society; ${ }^{215}$ Rousseau himself believed that the state of nature,

210. In Émile, Rousseau writes that the laws of nature are "mysteries ... beyond the region of sense; we think we can penetrate them by the light of reason, but we fall on our imagination." Horowitz, supra note 177, at 48 (quoting JEAN-JACQUES ROUSSEAU, ÉMILE 260 (Barbara Foxley trans., Dutton 1976) (1762)).

211. Rousseau, supra note 193, at 102.

212. HorowiTZ, supra note 177 , at 48 (emphasis added).

213. Kremer-Marietti, supra note 185, at 184 ("L'originalité de Rousseau consiste en l'habileté de savoir s'y prendre pour soupçonner qu'une conception dépend de la culture et n'a rien à voir avec la nature.").

214. In Hobbes's state of nature, "The war not only goes on, but fear-that passion to be reckoned on-is insufficiently sobered with the thought of other men's power." S.A. STATE, Thomas Hobbes AND the DEBATE OVER NATURAL LAW AND RELIGION 158 (1991).

215. Rousseau urged,

Above all, let us not conclude with Hobbes that because man has no idea of goodness, man is naturally evil; that he is vicious because he does not know virtue .... Hobbes saw very clearly the defect of all modern definitions of natural right; but the consequences he draws from his own definition show that he takes it in a sense which is no less false.

Rousseau, supra note 193, at 128-29. 
if it ever existed, was a state of peace, not war. ${ }^{216}$ Rousseau criticized Hobbes in order to demonstrate that definitions of "natural right" seldom conform to a "true" idea of nature. ${ }^{217}$ Rousseau understood that philosophers tend to dub those elements of social relations that corroborate their already existing political theories as "natural." Similarly, Julie equated the decrees of her father and society with the laws of nature..$^{218}$ She unwittingly created an image of nature that conformed with her life experience. In implicit recognition of this, Julie eventually embraced the love she had rejected in the name of "nature." 219

Rousseau's immensely successful novel La Nouvelle Hélö̈se thus helped to set the intellectual framework in which the French bioethics debates occurred more than two hundred years later. As the following discussion will illustrate, his ideas about the complex interplay between family, nature, and ethics were reformulated in the rhetoric of the contemporary bioethics debates. Close joint analysis of Rousseau's novels and the transcripts of the bioethics debates reveals, however, that Rousseau's ideas were greatly transmuted in the contemporary bioethics debates. Like Rousseau and other Enlightenment philosophers, the legislators appealed to "nature" to inform and legitimate their political decisions. But like the philosophers Rousseau criticized, the legislators seem to have based ethical judgments on a static vision of nature that reflected the status quo in order to justify limiting access to ART. A joint analysis of Rousseau's novels and the transcripts of the bioethics debates therefore provides a particularly effective means of both understanding and critiquing the contemporary legislators' appeal to a static vision of "nature" as an ethical guide.

\section{B. Critiquing the Appeal to Nature in the Contemporary Bioethics Debates}

The rhetoric of "nature" and the "natural" was central to the contemporary bioethics debates, but the words were used as a justification for what the legislators already believed to be socially

216. See id. at 129 ("[T]his author ought to have said that since the state of nature is that in which care of our self-preservation is the least prejudicial to the self-preservation of others, that state was consequently the best suited to peace and the most appropriate for the human race.").

217. See id. at 128-29.

218. See supra notes 205-08 and accompanying text.

219. See supra note 209 and accompanying text. 
right. Medical advances, such as the ability to help post-menopausal women or homosexual couples have genetically related children, have caused the questions of the eighteenth century about the relationship between family, nature, and society to be asked with a new sense of urgency. ${ }^{220}$ For instance, Henri Gouhier of l'Académie Française observed near the end of the twentieth century that:

[t]he word conscience as used by Rousseau suggests the word nature. Since his insight on the road to Vincennes, Rousseau's thought seemed dedicated to a search for a lost nature; and he would not have been looking for it if he had found it. Now, could it be that the contemporary crisis of conscience is actually a crisis in the idea of nature; or, at least, could it be that the crisis in the idea of nature is a component of the contemporary crisis of conscience ${ }^{221}$

In the face of ART's potential challenge to the traditional family unit, society is once again looking to nature for answers to difficult political and ethical questions: "If we still have such a strong sentiment of the contemporary relevance of Rousseau's thought, it is undoubtedly because he emphasized the relationship between 'nature' and 'culture' in his philosophical writings . . .,"222

In the minds of the 1994 French legislators, the "cultural crisis" at hand was the possible transformation of the heterosexual biparental family norm by unrestricted use of ART. Unwilling to ratify the "possible" as the "natural," the legislators attempted to institute a certain idea of nature as an ethical arbiter. ${ }^{223}$ They used nature as a limit, a means of erecting controls and ethical boundaries around the

220. See supra note 8 and accompanying text. As Henri Gouhier notes, "If we have such a strong sense of the contemporary relevance of Rousseau, it is undoubtedly because he emphasized the relationship between 'nature' and 'culture' . . ." Henri Gouhier, Preface to JEAN-JACQUES ROUSSEAU ET LA CRISE CONTEMPORAINE DE LA CONSCIENCE 6 (Editions Beauchenese, 1980) ("Si nous avons le sentiment si vif d'une actualité de Rousseau, ç'est sans doute parce qu'il a fait passer au premier plan de la philosophie la question des rapports de la $<<$ nature $>>$ et de la $<<$ culture $>>$....").

221. Gouhier, supra note 220 , at 5 ("Le mot $<<$ conscience $>>$ sous la plume de Rousseau appelle le mot $<<$ nature. $>>$ Depuis l'illumination sur la route de Vincennes, la pensée de Rousseau semble vouée à la recherche d'une nature perdue et qu'il ne chercherait pas s'il ne l'avait retrouvée. Or la crise contemporaine de la conscience ne serait-elle pas une crise de l'idée de nature ou du moins la crise de l'idée de nature ne serait-elle pas une des composante de la crise contemporaine de la conscience? ... Peut-on se réferer à la nature pour surmonter la crise de notre culture?").

222. Id. ("Si nous avons le sentiment si vif d'une actualité de Rousseau, c'est sans doute parce qu'il a fait passer au premier plan de la philosophie la question des rapports de la $<<$ nature $>>$ et de la $<<$ culture $>>. . . . ")$.

223. See infra notes 228-35 and accompanying text. 
use of ART. Thus, although the legislators attempted to make a transfer from nature to ethics like the Enlightenment philosophers, they seem to have fallen into the trap of conflating the existing social order for the "natural" order. ${ }^{224}$ For example, even though it is now possible for post-menopausal women to bear children, the French legislature did not accept this option as "natural" and therefore "right." The French legislators defined nature as the observable life processes that existed without the technological interference of man. ${ }^{225}$ Consequently, reproduction of heterosexual couples was deemed "natural," and therefore permissible, because only fertile heterosexuals can procreate without the help of ART.

These ideas are manifest in the rhetoric used during the bioethics debates. For example, on a radio program broadcast on National Public Radio in 1994, Dr. Jeanne Françoise Jirah, the French Director General, Ministry of Social Affairs, said this of ART:

The aim is not to create new rights. Bearing a child when you are older than the usual age, is a new right. Bearing a child when you are in a couple with another women [sic], it's a new right. It's not a medical choice. It's a choice by the society itself. What do we want to do with the scientific and medical progress? Obviously, in France, the answer by the government, and the parliament, are, "We don't want to create new rights, just restore the rights which were diminished by the disease, by sterility, because it made sense to."226

Dr. Jirah seems to have assumed that what is observable biologically is natural and therefore a "right." Helping sterile couples is only restorative, in her opinion, and is, therefore, morally acceptable. ${ }^{227}$ In contrast, helping a homosexual couple who would not be able to have a child without the benefit of technology is a "new" (read "unnatural") right. The logic seems to be that since only heterosexual couples are anatomically equipped to procreate, they should be the only ones allowed to procreate-even if the technology exists to enable other couples to give birth, too.

224. Anne Fagot-Largeault, a member of the CCNE, observed that "one does not substitute an a priori order for the natural order: one fixes the existing order." Fagot-Largeault, supra note 51, at 201 ("on ne substitue pas à l'ordre naturel un ordre a priori: on raccommode celui qui existe").

225. See infra notes 228-35 and accompanying text.

226. Morning Edition: French Government Will Control Who Has Test-Tube Babies (National Public Radio broadcast, May 5, 1994).

227. See id. 
The assumption that existing biological processes can serve as an ethical standard is also evident in the text of the French law itself. The law provides: "Medically assisted procreation is intended to... remedy infertility due to pathological conditions...."228 The law explicitly states that the technology may only be used if the need has been medically legitimated. ${ }^{229}$ Moreover, the 1994 bioethics laws define ART as the "clinical and biological practices that permit in vitro fertilization, the transfer of embryos, artificial insemination and all technology with equivalent effects that enable procreation outside of the natural process. ${ }^{230}$ In other words, ART may only be used to help a pre-existing biological process that is currently not functioning. Specifically, it may only be used to help heterosexual couples who are prevented from procreating because they are sterile.

The legislators explicitly referred to nature as an ethical arbiter that could help them develop and legitimate the laws during the parliamentary debates. For example, Madame Françoise de Panafieu of the RPR referred to the "laws of nature" to support condemning post-menopausal insemination: "In this proposed law, we have to take into consideration the interest of the woman. Wanting to force nature, and wanting someone past childbearing age to procreate at all costs does not conform to that interest.",231

This same mode of reasoning surfaced in representative Simone Veil's comment:

We can accept to correct nature's shortcomings, but not going against nature in allowing, as we have seen recently in Italy, late-life pregnancies, prejudicial to the child and dangerous to the mother's health. We can also not arrange for births of children without fathers in allowing either the post mortem insemination or implantation of an embryo after the death of a spouse. ${ }^{232}$

228. Law No. 94-654 of July 30, 1994, J.O., July 30, 1994, p. 11,062; D.S.L. 1994, 29, 411 ("L'assistance médicale à la procréation est déstinée à répondre à la demande parentale d'un couple. Elle a pour objet de rémédier à l'infertilité dont le caractère pathologique a été médicalement diagnostiqué.").

229. See id.

230. Id.

231. Id. at 2863 ("[D]ans un texte de loi comme celui qui nous est proposé, nous devons certes prendre en compte ... l'intérêt de la femme .... Vouloir forcer la nature et faire procréer à tout prix qui a dépassé l'âge naturel de la procréation, n'est pas conforme à cette préoccupation.").

232. Id. at 2743. The original French reads:

On peut admettre de corriger les défaillances de la nature, mais non d'aller à son encontre en permettant, comme on l'a vu récemment en Italie, des maternités 
Thus, Veil, like Panafieu, seemed to presume that observation of the life processes pre-existing the invention of ART reveals the morally superior dictates of "nature." The "natural," therefore, as Rousseau suggested of certain contemporaries, was defined in a way that merely confirmed what the legislators believed to be socially "right."

Mattei likewise used "nature" to justify his exclusion of homosexual or post-menopausal women from access to ART during another National Assembly session:

Yes, these procedures have been used for twenty years... and families created from their use. Aberrations have occurred, and they must be prevented. Therefore, we have wanted to define very clearly the scope of medical assistance for reproduction: pathological infertility, medically defined for a couple, a man and a woman who are living and who give informed consent to insemination or implantation. In my understanding, this medical procedure is a last resort, and it is out of the question to accept its use post mortem or after the age of menopause. Its use would be a corruption of medical practice, a contradiction of nature, a perversion of the idea of what it is to be a child. ${ }^{233}$

Mattei decries procreative practices that go against his idea of the traditional family as unnatural "aberrations." Thus, "natural" for Mattei also appears to consist of those relationships that he currently observes and approves of in French society. His definition of nature represents a rather static view that has been derived from personal experience, and not the objective norm he purports it to be. Unwilling to permit the proliferation of other familial models, Mattei excludes them as unnatural. Thus, Mattei's reasoning resembles a selective

tardives, préjudiciables à l'enfant et dangereuses pour la santé de la mère. On ne peut non plus organiser la naissance d'enfants orphelins de père en permettant l'insémination post mortem ou l'implantation d'un embryon après le déces du conjoint.

Id.

233. Id. at 2757 (emphasis added). The original French reads:

Oui, cela fait vingt ans que ces techniques s'appliquent ... que des familles sont ainsi construites. Des dérives apparaissent, il faut les empêcher. Nous avons donc voulu très clairement définir le cadre de cette assistance médicale à la procréation: l'infertilité pathologique, médicalement constatée chez un couple, homme et femme, vivants et consentants préalablement à l'insémination ou à l'implantation. Dans notre esprit, cette technique médicale est un recours ultime, et il n'est pas question de l'accepter post mortem ou passé l'âge de la ménopause. Ce serait un dévoiement de la médecine, un contresens par rapport à la nature, une perversion de l'idée de l'enfant. 
reading of Enlightenment ideas: he condones a certain mode of family that he believes would be beneficial to society, but he supports this heterosexual norm on the basis of a limited concept of nature that appears akin to the ideas of thinkers Rousseau criticized.

Thus, the legislators justified limiting access to ART, and attempted to contain the threat of "reproductive anarchy," with an appeal to a rather limited and static view of nature. The legislators believed that their observation of biological processes pre-existing the advent of ART could provide an immutable a priori moral order intuitively accessible to man. The legislators' arguments echoed Enlightenment notions of nature's ability to serve as an ultimate ethical arbiter, but they reflect a less nuanced view of the dynamic relationship between nature and ethics than that articulated by Rousseau. Rather, the reasoning underlying the 1994 bioethics legislation seems to run directly counter to Rousseau's caution against uncritically confounding predominant social customs with the "natural."

\section{CONCLUDING THOUGHTS: LAW AND LITERATURE}

The debate about bioethics is far from complete; it did not end with the consensus achieved with France's bioethics laws. In effect, the French legislation can be understood as a relatively static effort to hit several rapidly moving targets: family, nature, and ART. As these targets continue to move, thinking about bioethics issues will also have to evolve.

Rereading eighteenth-century novels such as Rousseau's $L a$ Nouvelle Héloïse reveals that literature can play an important role in this ongoing dialogue surrounding biomedical ethics. As the discussion in Parts II and III illustrated, Rousseau used the novel as a means of disseminating various ideas about the relationship between family, nature, and ethics to the public. ${ }^{234}$ The concepts of nature and what forms of human conduct are natural had serious implications for Rousseau's characters. Rousseau's works profoundly affected French sensibilities about the importance of child-rearing and reproductive

234. "Our lessons can never be useful, unless they are so written as to catch the attention of those for whose benefit they were calculated." 4 RousSEAU, supra note 139, at xxi. "During the eighteenth century, one preferred to question the public about problems to which there were as yet no answers." McDonald, supra note 5, at 70 ("Au XVIII siècle on préférait interroger le public sur des problèmes auxquels justement on n'avait pas encore de réponse." (quoting Michel Foucault, Qu'est-ce que les Lumières?, 309 MAGAZINE LITTÉRAIRE 61, 63 (Apr. 1993))). 
practices to the well-being of society. Thus, Enlightenment thinkers like Rousseau not only laid the polemical groundwork for the 1994 bioethics debates, but they also bequeathed an invaluable literary means of conceptualizing and exploring ethical questions. ${ }^{235}$

Due to legislators' inherently conservative nature, the work of lawmaking bodies, while very important, does not provide an adequate means of comprehensively addressing bioethics questions. Bioethics questions are continually evolving, but the laws made to address them have difficulty adapting to rapid technological changes because they are geared towards protecting existing norms. Harvard Professor of Romance Languages and Literature Christie McDonald explains, "[T]he law cannot provide a founding for ethical thought, because it is designed less to innovate than protect tradition, fitting principles (philosophical, moral, legal) with facts has seemed like a process of updating in a constantly outdated system.,"236

The 1994 bioethics laws reflected a static vision of family and nature that was more in line with protecting tradition than the more dynamic reality. Constrained by the need to formulate a consensus

235. In fact, contemporary French scientists are themselves turning to literature to help them grapple with bioethics questions. For example, Henri Atlan, a French biologist who is also a long-time member of the CCNE, promoted the value of stories to biomedical ethics in a recent book: "Ethics, virtues, are taught through stories. Learning about good and evil occurs not so much through philosophy, science or rational analysis of logic, but rather through identification with situations or individuals." HENRI ATLAN \& CATHERINE BOUSQUET, QUESTIONS DE VIE: ENTRE LE SAVOIR ET L'OPINION [QUESTIONS OF LIFE: IN BETWEEN KNOWLEDGE AND OPINION] 14 (1994) ("L'éthique, la vertu s'enseignent par ces contes-là. L'enseignement du bien et du mal ne se fait pas tant par la philosophie, la science ou des analyses logiques rationnelles, que par une identification à des situations ou des individus.").

French senator Guy Cabanel referred to the parable about biblical prophet Jeremy Atlan cited in Questions to support disposal of artifical embryos created with ART:

As for the argument that thawing frozen embryos amounts to killing them, I have just one answer that I found in a recent book by Henri Atlan, and which is in a sense is the parable of Jeremiah .... To those who treat the problem on a moral level, I would respond, therefore, that children produced artificially in the laboratory are not the children of God.

Debates, supra note 158, at 3394.

Moreover, Jacques Testart, one of the scientists who helped bring about the birth of the first French test-tube baby, has started writing novels and stories as a means of exploring the ethical implications of biomedical research. Testart examined the ethics of using frozen DNA material to give life to long-extinct species (such as man's Cro-Magnon ancestors) in a short story published in Le Monde Diplomatique. See Jacques Testart, La leçon de Cro-Magnon, LE Monde DiplomatiQue, Mar. 1994, at 28. Testart also recently published a novel entitled Simon l'Embaumeur ou la solitude du magicien that addresses the interaction between science and the media and also criticizes the scientific establishment itself. See JACQUES TESTART, SIMON L'EMBAUMEUR OU LA SOLITUDE DU MAGICIEN 19-25 (1987).

236. McDonald, supra note 147 , at 72. 
and provide set rules for citizens to follow, the legislators drafted laws that build on the Enlightenment tradition but missed some of the important nuances of Enlightenment thought. Philippe Lazar, director of the French biomedical agency INSERM, explained,

Shouldn't one be afraid that [a bioethics committee takes] the risk of confiscating the national reflection on those questions which were submitted to it, by reserving for itself, as they acutely strive to arrive each time at a good consensus, the debate which constitutes itself the essence of ethical reflection among a group or society. ${ }^{237}$

Arguably, non-consensus and ambiguity form the very heart of any meaningful ethical discussion. A rereading of Rousseau's novels indicates that literature complements the work of legal bodies in providing a forum where nonconsensus can be maintained so that ethical questions can be explored more fully. Gary Wihl put it thus, "As homogeneous standards weaken, the language of the novel points the way towards a genuinely plural discourse that addresses the same concerns as social theory." 238 Consensus is antithetical to literature; the existence of irreconcilable paradoxes and contradictions form the very basis of literature's power: "Novels, in short, are full of perspicuous observations arising from a plurality of descriptions and a sustaining rather than canceling of ambiguity. Literature, therefore, can provide a freer sphere of ethical reflection that can be incorporated into the more restrictive legal text. The evolution of bioethics questions and society's understanding of them will be an important, continuing dialogue that will involve legislators, scientists, ethicists, and historians of science, as well as writers and citizens.

237. Philippe LaZAR, L'Ethique BiomedicAle EN QUeStion 26-27 (1996).

238. Gary Wihl, Novels as Theories in a Liberal Society, in CONSTRUCTIVE CRITICISM: THE HUMAN SCIENCES IN THE AGE OF THEORY 101, 101 (Martin Kreisworth \& Thomas Carmichael eds., 1996).

239. Id. at 113. 